\title{
Chemodiversity of Ladder-Frame Prymnesin Polyethers in Prymnesium parvum
}

Rasmussen, Silas Anselm; Meier, Sebastian; Andersen, Nikolaj Gedsted; Blossom, Hannah Eva; Duus, Jens Øllgaard; Nielsen, Kristian Fog; Hansen, Per Juel; Larsen, Thomas Ostenfeld

Published in:

Journal of Natural Products

Link to article, DOI:

10.1021/acs.jnatprod.6b00345

Publication date:

2016

Document Version

Publisher's PDF, also known as Version of record

Link back to DTU Orbit

Citation (APA):

Rasmussen, S. A., Meier, S., Andersen, N. G., Blossom, H. E., Duus, J. Ø., Nielsen, K. F., Hansen, P. J., \& Larsen, T. O. (2016). Chemodiversity of Ladder-Frame Prymnesin Polyethers in Prymnesium parvum. Journal of Natural Products, 79(9), 2250-2256. https://doi.org/10.1021/acs.jnatprod.6b00345

\section{General rights}

Copyright and moral rights for the publications made accessible in the public portal are retained by the authors and/or other copyright owners and it is a condition of accessing publications that users recognise and abide by the legal requirements associated with these rights.

- Users may download and print one copy of any publication from the public portal for the purpose of private study or research.

- You may not further distribute the material or use it for any profit-making activity or commercial gain

- You may freely distribute the URL identifying the publication in the public portal 


\title{
Chemodiversity of Ladder-Frame Prymnesin Polyethers in Prymnesium parvum
}

\author{
Silas Anselm Rasmussen, ${ }^{\dagger}$ Sebastian Meier, ${ }^{\ddagger}$ Nikolaj Gedsted Andersen, ${ }^{\S}$ Hannah Eva Blossom, ${ }^{\S}$ \\ Jens Øllgaard Duus, ${ }^{\dagger}$ Kristian Fog Nielsen, ${ }^{\dagger}$ Per Juel Hansen, ${ }^{*}, \S$ and Thomas Ostenfeld Larsen ${ }^{*}, \dagger$
}

${ }^{\dagger}$ Department of Biotechnology and Biomedicine, Technical University of Denmark, Søltofts Plads 221, 2800 Kgs. Lyngby, Denmark

${ }^{\ddagger}$ Department of Chemistry, Technical University of Denmark, Kemitorvet 207, 2800 Kgs. Lyngby, Denmark

${ }^{\S}$ Marine Biological Section, Department of Biology, Copenhagen University, Strandpromenaden 5, 2100 Helsingør, Denmark

\section{Supporting Information}

\begin{abstract}
Blooms of the microalga Prymnesium parvum cause devastating fish kills worldwide, which are suspected to be caused by the supersized ladder-frame polyether toxins prymnesin-1 and -2 . These toxins have, however, only been detected from $P$. parvum in rare cases since they were originally described two decades ago. Here, we report the isolation and characterization of a novel B-type prymnesin, based on extensive analysis of 2D- and 3D-NMR data of natural as well as $90 \%{ }^{13} \mathrm{C}$ enriched material. B-type prymnesins lack a complete 1,6-dioxadecalin core unit, which is replaced by a short acyclic $\mathrm{C}_{2}$ linkage compared to the structure of the original prymnesins. Comparison of the bioactivity of prymnesin-2 with prymnesin-B1 in an RTgill-W1 cell line assay identified both compounds as toxic in the low nanomolar range. Chemical investigations by liquid chromatography highresolution mass spectrometry (LC-HRMS) of 10 strains of $P$. parvum collected worldwide showed that only one strain produced the original prymnesin-1 and -2 , whereas four strains produced the novel B-type prymnesin. In total 13 further prymnesin analogues differing in their core backbone and chlorination and glycosylation patterns could be tentatively detected by LC-MS/ HRMS, including a likely C-type prymnesin in five strains. Altogether, our work indicates that evolution of prymnesins has yielded a diverse family of fish-killing toxins that occurs around the globe and has significant ecological and economic impact.
\end{abstract}

$\mathrm{B}$ looms of ichthyotoxic (fish-killing) microalgae are a recurring phenomenon in coastal and river waters, with huge impacts on wild fish stocks as well as caged fish. Such blooms have detrimental economical consequences for the local communities, fish farmers, and recreational and commercial fishers. An algal species that has been associated with massive fish kills in at least 14 countries is the haptophyte Prymnesium parvum (the golden alga). ${ }^{1}$ In recent years, problems with $P$. parvum have spread to all southern states in the USA, ${ }^{2}$ where it has become endemic in several river systems, with estimated economic losses higher than $\$ 10$ million. ${ }^{3}$ Consequently, programs have been initiated in countries such as the USA, Norway, and Denmark in order to assess the ecological and economic impacts of $P$. parvum blooms and to develop management options for controlling fish kills. ${ }^{4}$ The possible ichthyotoxic components of $P$. parvum have been extensively studied, ${ }^{5}$ but due to their complex structures and low abundance, it was not until 1996 that Igarashi et al. ${ }^{6}$ successfully isolated and elucidated the structure of the two large polyether ladder-frame compounds, prymnesin-1 and -2 . Later, the relative configuration of the prymnesins was revised by the Yasumoto group using synthetic models. ${ }^{7-10}$ Despite the numerous $P$. parvum blooms that have occurred during the last two decades, prymnesin-2 has only once been tentatively detected again by liquid chromatography combined with highresolution mass spectrometry (LC-HRMS). ${ }^{11}$ Other groups have isolated and suggested "golden algae toxins" and fatty acid amides ${ }^{12-14}$ as the principle toxins of $P$. parvum. However, we have recently shown that these compounds are not ichthyotoxic at ecologically relevant concentrations. ${ }^{15}$ On the basis of these latter findings, our attention was drawn toward the prymnesins. We hypothesized that the reason that so few groups have been able to detect the original prymnesins could be that the structural diversity of prymnesin-type compounds is larger than previously realized. The current study supported our hypothesis, because isolation and detailed analysis of $2 \mathrm{D}$ - and 3D-NMR data showed the novel compound prymnesin-B1 to have a different polyether backbone structure compared to the original prymnesins, altogether defining a novel B-type prymnesin. Furthermore, LC-MS/HRMS analysis of 10 strains of $P$. parvum collected worldwide indicated the B-type prymnesin to be more abundant than the original prymnesins.

Received: April 19, 2016

Published: August 23, 2016 


\section{Chart 1}
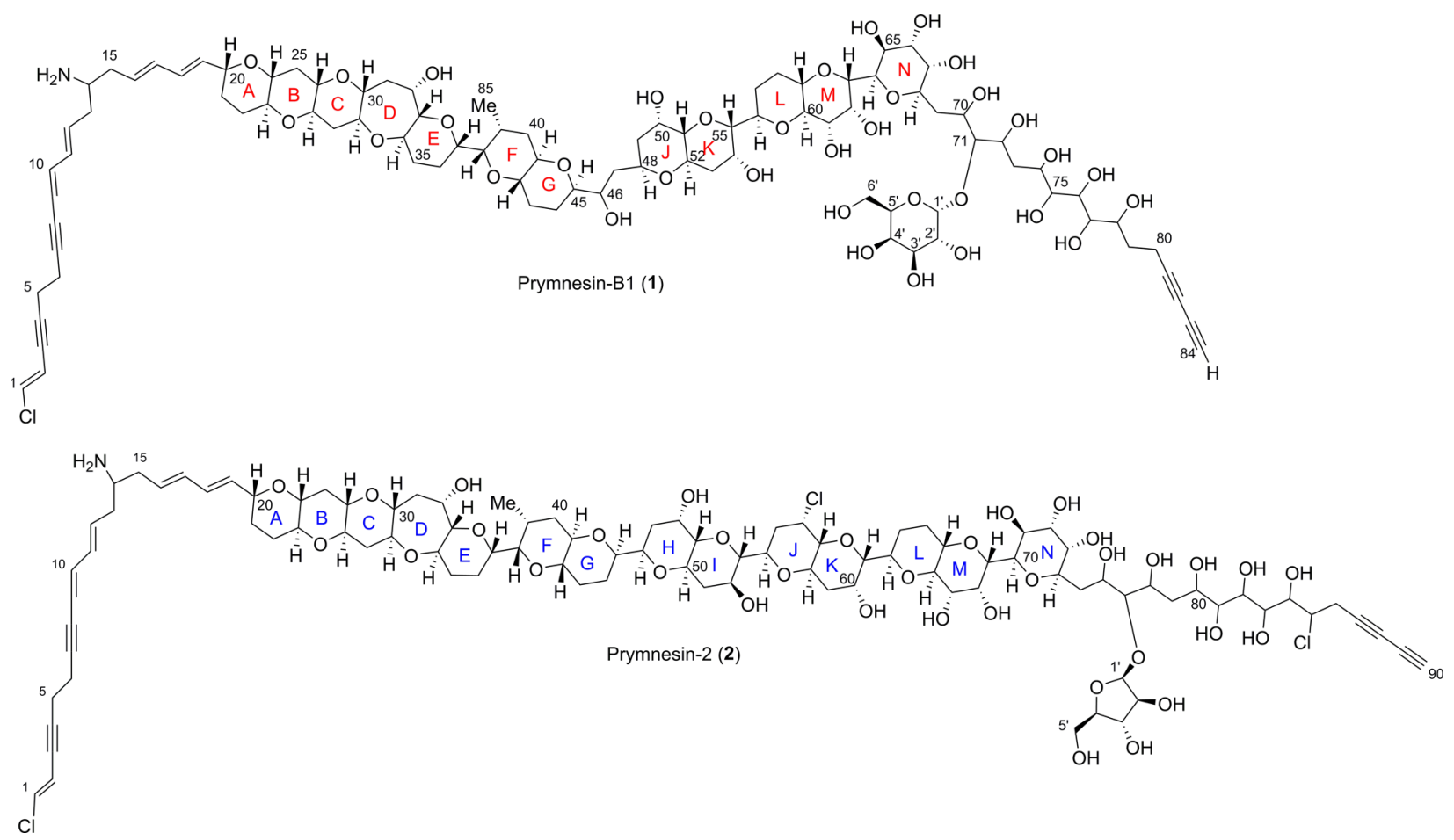

\section{RESULTS AND DISCUSSION}

Purification of Prymnesins. Prymnesin-B1 (1) was isolated from a Danish strain of $P$. parvum $\mathrm{K}-0081$, as this particular strain was found to be highly toxic toward rainbow trout and did not produce the known prymnesins. ${ }^{15}$ By screening different solid-phase columns, we successfully established an efficient normal-phase purification strategy that uses amino-functionalized silica. This strategy resulted in a highly enriched fraction that finally was purified by semipreparative reversed-phase HPLC to afford $1.8 \mathrm{mg}$ of prymnesin-B1. In order to obtain heteronuclear NMR assignment spectra for structural studies, we also isolated $1.0 \mathrm{mg}$ of $90 \%$ uniformly ${ }^{13} \mathrm{C}$-enriched prymnesin-B1 from a culture grown in artificial seawater containing $180 \mathrm{mg} / \mathrm{L} \mathrm{NaH}^{13} \mathrm{CO}_{3}$. Using a similar approach we isolated prymnesin-2 for biological testing from a $100 \mathrm{~L}$ cultivation of the strain UTEX-2797.

NMR Spectroscopic Elucidation. The elucidation of the structure of prymnesin-B1 was largely achieved through extensive interpretation of 2D COSY, TOCSY, and NOESY NMR spectroscopy at natural isotope abundance, as well as by $3 \mathrm{D}{ }^{1} \mathrm{H}-{ }^{13} \mathrm{C}$ HSQC-TOCSY, ${ }^{1} \mathrm{H}-{ }^{13} \mathrm{C}$ HSQC-NOESY, HCCHTOCSY NMR, and constant-time ${ }^{1} \mathrm{H}-{ }^{13} \mathrm{C}$ HSQC (CTHSQC) spectra on the $\sim 90 \%{ }^{13} \mathrm{C}$-enriched version. Although hampered by a very low solubility of the isolated prymnesin-B1 in $\mathrm{CD}_{3} \mathrm{OD}$, which resulted in relatively poor signal-to-noise ratio, the ${ }^{1} \mathrm{H}$ NMR spectroscopic data (Figure S2) turned out to be consistent with those of other ladder-like polyethers. ${ }^{17}$ The ${ }^{1} \mathrm{H}$ and COSY spectra revealed 10 allylic protons. Additionally, the HSQC spectrum showed one methyl group, 24 methylene groups, and 47 oxygenated carbons. Furthermore, the HSQC spectrum showed an anomeric proton, confirming the presence of an attached carbohydrate.

The backbone structure was established through careful analysis of COSY and TOCSY spectra. With these experiments we initially identified the following structural parts: $\mathrm{H}-1$ to $\mathrm{H}-$
48, H-49 to H-54, H-55 to H-73, and H-74 to H-80. On the basis of the extracted coupling constants all double bonds were found to be of $E$ configuration. The connection $\mathrm{H}-48 / \mathrm{H}-49$ was not clear in the COSY data due to signal overlap, but was clarified from an HCCH-TOCSY correlation from H-48 to H50. Furthermore, the COSY connectivity was interrupted at $\mathrm{H}$ 54 due to the equatorial position of this proton relative to $\mathrm{H}$ 55 , resulting in a very small coupling constant. The connection was made by a NOE observed between $\mathrm{H}-54$ and $\mathrm{H}-55$. The connection between the two H-73 protons and H-74 showed no COSY cross-peak and was therefore established with the observed correlations in the HCCH-TOCSY experiment. The poly-hydroxylated side chain showed some overlapping proton signals, hampering the elucidation by COSY correlations alone. Analysis of ${ }^{1} \mathrm{H}-{ }^{13} \mathrm{C}$ HSQC-TOCSY planes and $\mathrm{HCCH}-$ TOCSY planes aided the elucidation process. In addition, NMR data obtained at a range of temperatures were used to resolve overlapping signals. Thus, signals that overlapped at 313 $\mathrm{K}$ were partly resolved at $293 \mathrm{~K}$. The connection of $\mathrm{H}-70$ to $\mathrm{H}-$ 72 was hampered by the similar chemical shifts of $\mathrm{H}-70$ and $\mathrm{H}-$ 71 , but the HCCH-TOCSY experiment at $293 \mathrm{~K}$ showed that $\mathrm{H}-72$ had correlations to the two resolved protons, $\mathrm{H}-70$ and $\mathrm{H}-71$. Positioning of the amine and chlorine atoms was based on the ${ }^{13} \mathrm{C}$ chemical shifts of attached carbons and was consistent with chemical shift values and positions observed in prymnesin- 1 and -2 . Due to the small amount of prymnesin-B1 in solution, we did not observe any of the quaternary carbons $\mathrm{C}-3$, C-8, C-81, C-82, and C-83 or the acetylenic $\mathrm{C}-\mathrm{H}$ (pos 84 ) in the HMBC spectrum. A long-range (LR) optimized HCCT-HSQC using ${ }^{n} J_{\mathrm{CH}}=12 \mathrm{~Hz}$ (LR-HSQC) showed weak correlations from $\mathrm{H}-5$ and $\mathrm{H}-6$ to $\mathrm{C}-4$ and $\mathrm{C}-7$, respectively (see Figure S6). Furthermore, the coupling constants ${ }^{5} \mathrm{H}_{\mathrm{H}-2, \mathrm{H}-\mathrm{5}}=$ ${ }^{5} J_{\mathrm{H}-6, \mathrm{H}-9}=3 \mathrm{~Hz}$ were of similar values to those reported by Igarashi et al., ${ }^{16}$ further confirming the alkynyl carbon atoms (C-3/C-4 and C-7/C-8). 
A

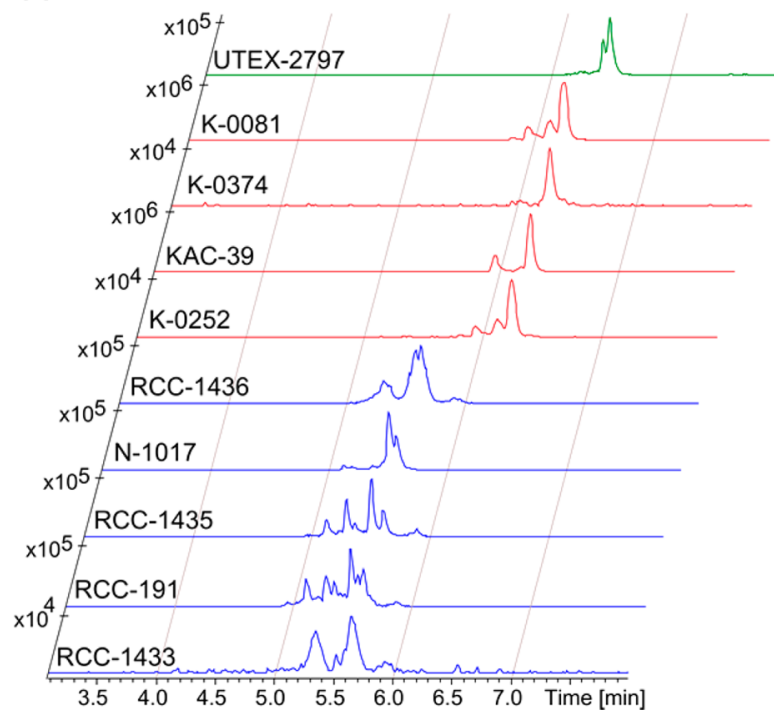

B
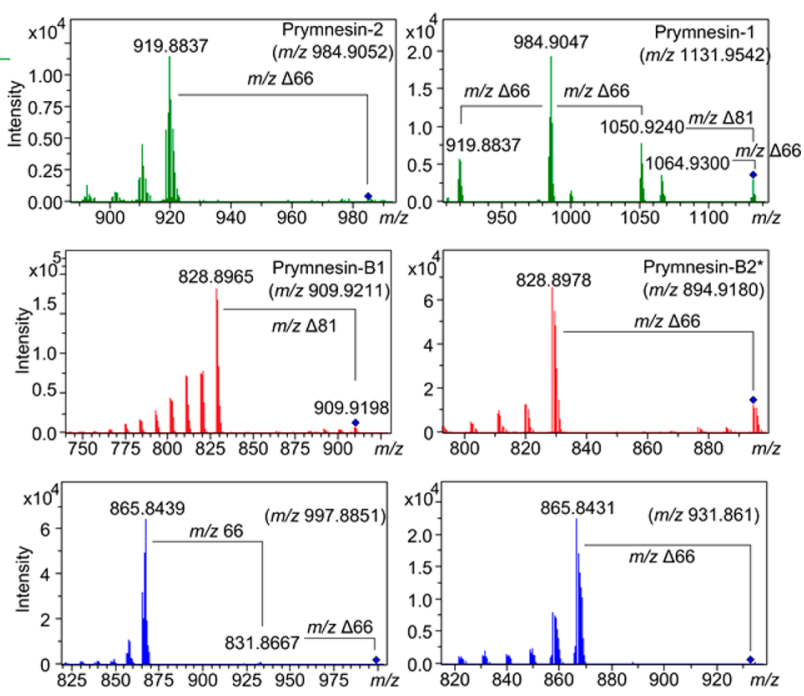

Figure 1. LC-MS/HRMS screening of 10 P. parvum strains. (A) Summed EICs (doubly charged) of all prymnesin-like molecules in 10 worldwidedistributed strains of $P$. parvum. Green EIC was created for original prymnesin-1 and -2. Red EICs show B-type prymnesins. Blue EICs show tentatively identified C-type prymnesins. (B) MS/HRMS spectra of $[\mathrm{M}+2 \mathrm{H}]^{2+}$ : (top) prymnesin-1 and -2 , (middle) prymnesin-B1 and -B2, (bottom) tentatively assigned C-type prymnesins. $\Delta 66$ shows a loss of a pentose $(\mathrm{m} / \mathrm{z} 66.021$, doubly charged) and $\Delta 81$ a loss of a hexose $(\mathrm{m} / z$ 81.026, doubly charged). Asterisk (*) denotes tentatively characterized by MS/MS, UV, and chiral-phase GC-MS.

Most ether ring closures were determined based on the strong NOE correlations observed across the 1,3-diaxial protons in the individual ether rings, as previously noted for other ladder-like polyether natural products. ${ }^{17}$ Hence the rings A to $\mathrm{G}$ and $\mathrm{J}$ to $\mathrm{N}$ were determined by NOE correlations between H-20/H-24, H-23/H-27, H-26/H-30, H-29/H-34, H33/H-37, H-38/H-42, H-41/H-45, H-56/H-60, H-59/H-63, and $\mathrm{H}-64 / \mathrm{H}-68$. The ring closures of rings $\mathrm{J}$ and $\mathrm{K}$ were more challenging to determine due to severe signal overlaps and due to the fact that no ether-forming NOE correlations could be observed from H-46 for the continuation of the trans-1,6dioxadecalin ladder, as seen in prymnesin-1 and prymnesin- 2 .

In order to elucidate the ether connectivities, deuterium exchange experiments in $\mathrm{CD}_{3} \mathrm{OH}$ and $\mathrm{CD}_{3} \mathrm{OD}$ were carried out. These exchange experiments identify ether linkages through a deuterium isotope effect on HSQC signals of alcohol, but not on ether groups. ${ }^{18,19}$ This procedure clearly showed that C-46, C-50, and C-54 as well as C-32, C-61, C-62, C-65, C-66, C-67, C-70, C-72, C-74, C-75, C-76, C-77, and C78 were hydroxy-bearing carbon atoms, as they all shifted $0.1-$ $0.2 \mathrm{ppm}$ from their ${ }^{13} \mathrm{C}$ chemical shift in $\mathrm{CD}_{3} \mathrm{OD}$; see Figure S5. Consequently, these exchange experiments established the connectivity of rings $\mathrm{J}$ and $\mathrm{K}$ as an additional dioxadecalin ladder ring system (similar to that of prymnesin 2) with ether linkages between C-48 and C-52 (consistent with an inconclusive NOE correlation observed near the diagonal of the NOESY spectrum) and between C-51 and C-55.

Importantly, this ring closure established a short linear $\mathrm{C}_{2}$ moiety of C-46 and $\mathrm{C}-47\left(-\mathrm{CHOH}-\mathrm{CH}_{2}-\right)$ that bridges the $\mathrm{G}$ and $\mathrm{J}$ rings, thus providing a new structural motif distinct from the established backbone of prymnesin-1 and -2. This structural motif is consistent with the similar proton chemical shifts observed for the two H-47 protons (1.61 and $1.69 \mathrm{ppm}$ ), which would not be expected if these had been part of a ring, as is the case in prymnesin-1 and -2 , where such protons are observed at 1.61 and $2.02 \mathrm{ppm}$, respectively. It is noteworthy that other notorious algal toxins such as brevisulcenals and maitotoxins similarly contain small acylic linkers (3-4 carbons long) as part of their large polyether structures. ${ }^{20}$

Relative Configuration of Prymnesin-B1. Assignment of the relative configuration of the rigid ring systems was based on the observed coupling constants measured with the DQFCOSY spectrum and from NOE correlations. These data are consistent with chair conformations and indicate that the cyclic ethers were trans-fused as observed in other ring structures of marine polyethers. ${ }^{16}$ Axial protons of methylene groups were observed shielded (1.46-1.95 ppm) relative to their equatorial counterparts $(2.04-2.35 \mathrm{ppm})$. We found that the relative configuration of rings $A$ to $G$ had adopted the same geometry as in prymnesin-1 and $-2 .{ }^{16}$ As originally observed for the linkage between rings $\mathrm{E}$ and $\mathrm{F}^{16}$ we also observed an intermediate coupling constant, ${ }^{3} J_{\mathrm{H}-37, \mathrm{H}-38}=7 \mathrm{~Hz}$, as well as a strong NOE correlation between $\mathrm{H}-37 / \mathrm{H}-38$, suggesting a twisted gauche rotamer. The configuration of the linkage between rings $\mathrm{E}$ and $\mathrm{F}$ in prymnesin-2 has also been studied using a synthetic model pointing toward the anti rotamer, ${ }^{8}$ but this model still did not explain the original observed NOE correlations for $\mathrm{H}-37 / \mathrm{H}-38$. $^{16}$

Rings $\mathrm{J}$ through $\mathrm{N}$ were likewise found to share the same relative configuration as seen in prymnesin-1 and -2 (for further details see the Supporting Information). The linkage between rings $\mathrm{M}$ and $\mathrm{N}$ was identified as the anti rotamer from a large coupling constant, ${ }^{3} J_{\mathrm{H}-63, \mathrm{H}-64}=9.5 \mathrm{~Hz}$. In agreement with this finding we did not observe any NOE correlations between these protons. For the $\mathrm{J}$ and $\mathrm{K}$ ring system of prymnesin-B1, we found the $\mathrm{OH}-50$ to be axial, as evident by a small coupling constant, ${ }^{3} J_{\mathrm{H}-50, \mathrm{H}-51}=4 \mathrm{~Hz}$. The axial conformation for OH-50 was further supported by two strong NOEs to $\mathrm{H}-49 \mathrm{a}, \mathrm{b}$ from $\mathrm{H}$ 50. Furthermore, $\mathrm{OH}-54$ was found to have adopted the axial geometry, based on the fact that no COSY cross-peak was observed between $\mathrm{H}-54 / \mathrm{H}-55$, indicative of a small coupling constant. The sequence of coupling constants $(12 / 4$ or $4 / 8.5$ $\mathrm{Hz}$ ) for the $\mathrm{H}-52 / \mathrm{H}-53 \mathrm{a}, \mathrm{b} / \mathrm{H}-54$ protons together with a strong NOE correlation from H-54 to H-53a,b also supported 
Table 1. NMR Spectroscopic Data ${ }^{a}\left(800 \mathrm{MHz}, \mathrm{CD}_{3} \mathrm{OD}\right)$ for Prymnesin-B1

\begin{tabular}{|c|c|c|c|c|c|c|c|c|}
\hline pos & $\delta_{\mathrm{C}}$ & $\delta_{\mathrm{H}}(J$ in $\mathrm{Hz})$ & pos & $\delta_{\mathrm{C}}$ & $\delta_{\mathrm{H}}(J$ in $\mathrm{Hz})$ & pos & $\delta_{\mathrm{C}}$ & $\delta_{\mathrm{H}}(J$ in $\mathrm{Hz})$ \\
\hline 1 & 129.2, $\mathrm{CH}$ & $6.58, \mathrm{~d}(13.9)$ & 33 & 84.4, $\mathrm{CH}$ & $3.00, \mathrm{~m}$ & 66 & 68.6, $\mathrm{CH}$ & $3.90, \mathrm{~m}$ \\
\hline 2 & 112.7, $\mathrm{CH}$ & 5.98 , dt $(13.7,2.1)$ & 34 & 74.4, $\mathrm{CH}$ & $3.67, \mathrm{~m}$ & 67 & 69.0, $\mathrm{CH}$ & $3.54, \mathrm{~m}$ \\
\hline 3 & n.d. & & 35 & $30.2, \mathrm{CH}_{2}$ & $1.45,2.09, \mathrm{~m}$ & 68 & 71.9, $\mathrm{CH}$ & $3.80, \mathrm{~m}$ \\
\hline 4 & 89.5/91.6, C & & 36 & 28.5, $\mathrm{CH}_{2}$ & $1.33,2.03, \mathrm{~m}$ & 69 & 34.6, $\mathrm{CH}_{2}$ & $1.53,2.03, \mathrm{~m}$ \\
\hline 5 & 19.0 & $2.52, \mathrm{~m}$ & 37 & $75.9, \mathrm{CH}$ & $3.18, \mathrm{~m}$ & 70 & $67.0, \mathrm{CH}$ & $4.06, \mathrm{~m}$ \\
\hline 6 & 19.0 & $2.54, \mathrm{~m}$ & 38 & $82.2, \mathrm{CH}$ & $3.33, \mathrm{~m}$ & 71 & 90.3, CH & $3.59, \mathrm{~m}$ \\
\hline 7 & 89.5/91.6, C & & 39 & 29.5, CH & $2.27, \mathrm{~m}$ & 72 & 69.0, CH & $4.03, \mathrm{~m}$ \\
\hline 8 & n.d. & & 40 & $36.2, \mathrm{CH}_{2}$ & $1.60,1.83, \mathrm{~m}$ & 73 & $33.2, \mathrm{CH}_{2}$ & $1.73,1.77$ \\
\hline 9 & $110.5, \mathrm{CH}$ & 5.57 , dd $(15.4,5.6)$ & 41 & 74.6, $\mathrm{CH}$ & $3.21, \mathrm{~m}$ & 74 & $68.8, \mathrm{CH}$ & $4.08, \mathrm{~m}$ \\
\hline 10 & 139.6, $\mathrm{CH}$ & 6.50 , dd $(15.7,10)$ & 42 & 79.4, $\mathrm{CH}$ & $2.96, \mathrm{~m}$ & 75 & 69.9, $\mathrm{CH}$ & $3.85, \mathrm{~m}$ \\
\hline 11 & 134.0, $\mathrm{CH}$ & 6.18 , dd $(14.8,10.7)$ & 43 & $28.8, \mathrm{CH}_{2}$ & $1.47,1.99, \mathrm{~m}$ & 76 & 73.8, $\mathrm{CH}$ & $3.71, \mathrm{~m}$ \\
\hline 12 & $127.4, \mathrm{CH}$ & 5.78 , ddt $(14.7,7.1,6.2)$ & 44 & $25.8, \mathrm{CH}_{2}$ & $1.47,1.88, \mathrm{~m}$ & 77 & $72.2, \mathrm{CH}$ & $3.60, \mathrm{~m}$ \\
\hline \multirow[t]{2}{*}{13} & 36.0, $\mathrm{CH}_{2}$ & $2.18, \mathrm{~m}$ & 45 & $80.4, \mathrm{CH}$ & $3.25, \mathrm{~m}$ & 78 & $69.5, \mathrm{CH}$ & $3.72, \mathrm{~m}$ \\
\hline & & $2.30, \mathrm{~m}$ & 46 & $71.4, \mathrm{CH}$ & $3.62, \mathrm{~m}$ & 79 & $32.5, \mathrm{CH}_{2}$ & $1.65,2.08, \mathrm{~m}$ \\
\hline 14 & $50.7, \mathrm{CH}$ & $2.95, \mathrm{~m}$ & 47 & $38.5, \mathrm{CH}_{2}$ & $1.61, \mathrm{~m}, 1.69, \mathrm{~d}(12.0)$ & 80 & $14.8, \mathrm{CH}$ & $2.45,2.50, \mathrm{~m}$ \\
\hline 15 & $36.0, \mathrm{CH}_{2}$ & $2.17,2.25, \mathrm{~m}$ & 48 & $70.5, \mathrm{CH}$ & $4.05, \mathrm{~m}$ & 81 & n.d. & \\
\hline 16 & $129.3, \mathrm{CH}$ & 5.70, ddt $(14.6,7.6,5.8)$ & 49 & $38.0, \mathrm{CH}_{2}$ & $1.58,1.90, \mathrm{~m}$ & 82 & n.d. & \\
\hline 17 & 134.1, $\mathrm{CH}$ & $6.11, \mathrm{dd}(14.7,10.2)$ & 50 & $65.4, \mathrm{CH}$ & $4.10, \mathrm{~m}$ & 83 & n.d. & \\
\hline 18 & 130.0, CH & 6.24 , dd $(15.4,10.5)$ & 51 & $80.4, \mathrm{CH}$ & $3.13, \mathrm{~m}$ & 84 & n.d. & n.d. \\
\hline 19 & $132.8, \mathrm{CH}$ & $5.60, \mathrm{dd}(15.0,5.9)$ & 52 & 66.4, $\mathrm{CH}$ & $4.00, \mathrm{~m}$ & 85 & 12.0, $\mathrm{CH}_{3}$ & $1.01, \mathrm{~d}(7.1)$ \\
\hline 20 & 77.5, $\mathrm{CH}$ & $3.96, \mathrm{~m}$ & 53 & $36.2, \mathrm{CH}_{2}$ & $1.59,2.19$ & $1^{\prime}$ & $103.3, \mathrm{CH}$ & $5.03, \mathrm{~b}$ \\
\hline 21 & 31.0, $\mathrm{CH}_{2}$ & $1.51,1.83, \mathrm{~m}$ & 54 & 64.7, $\mathrm{CH}$ & $4.18, \mathrm{~b}$ & $2^{\prime}$ & $69.5, \mathrm{CH}$ & $3.88, \mathrm{~m}$ \\
\hline 22 & 28.7, $\mathrm{CH}_{2}$ & $1.52,2.04, \mathrm{~m}$ & 55 & $82.3, \mathrm{CH}$ & $3.28, \mathrm{~m}$ & $3^{\prime}$ & 70.3, CH & $3.80, \mathrm{~m}$ \\
\hline 23 & $77.8, \mathrm{CH}$ & $3.04, \mathrm{~m}$ & 56 & 75.0, $\mathrm{CH}$ & $3.55, \mathrm{~m}$ & $4^{\prime}$ & 68.5, $\mathrm{CH}$ & $3.90, \mathrm{~m}$ \\
\hline 24 & 76.83, $\mathrm{CH}$ & $3.17, \mathrm{~m}$ & 57 & 28.0, $\mathrm{CH}_{2}$ & $1.41,2.09, \mathrm{~m}$ & $5^{\prime}$ & $72.0, \mathrm{CH}$ & $4.13, \mathrm{~m}$ \\
\hline 25 & 35.3, $\mathrm{CH}_{2}$ & $1.46,2.24, \mathrm{~m}$ & 58 & 28.4, $\mathrm{CH}_{2}$ & $1.57,2.05, \mathrm{~m}$ & $6^{\prime}$ & 61.3, $\mathrm{CH}_{2}$ & $3.71,3.78, \mathrm{~m}$ \\
\hline 26 & 76.6, $\mathrm{CH}$ & $3.00, \mathrm{~m}$ & 59 & 76.0, $\mathrm{CH}$ & $3.06, \mathrm{~m}$ & & & \\
\hline 27 & $76.8, \mathrm{CH}$ & $3.07, \mathrm{~m}$ & 60 & 78.7, $\mathrm{CH}$ & $3.34, \mathrm{~m}$ & & & \\
\hline 28 & $37.2, \mathrm{CH}_{2}$ & $1.37,2.27, \mathrm{~m}$ & 61 & $72.2, \mathrm{CH}$ & $3.65, \mathrm{~m}$ & & & \\
\hline 29 & 76.1, CH & $3.90, \mathrm{~m}$ & 62 & $68.9, \mathrm{CH}$ & $4.05, \mathrm{~m}$ & & & \\
\hline 30 & $80.0, \mathrm{CH}$ & $3.38, \mathrm{~m}$ & 63 & 75.4, $\mathrm{CH}$ & $3.54, \mathrm{~m}$ & & & \\
\hline 31 & $36.5, \mathrm{CH}_{2}$ & $1.95,2.35, \mathrm{~m}$ & 64 & 70.7, $\mathrm{CH}$ & $4.00, \mathrm{~m}$ & & & \\
\hline 32 & $70.8, \mathrm{CH}$ & $4.05, \mathrm{~m}$ & 65 & $70.6, \mathrm{CH}$ & $3.93, \mathrm{~m}$ & & & \\
\hline
\end{tabular}

${ }^{a}$ Chemical shifts are reported in $\mathrm{CD}_{3} \mathrm{OD}$ and referenced to $\delta_{\mathrm{H}} 3.31 \mathrm{ppm}$ and $\delta_{\mathrm{C}} 47.9 \mathrm{ppm}$ at $313 \mathrm{~K}$. n.d. $=$ not detected.

this finding (Figure S9). The linkage between rings $\mathrm{K}$ and $\mathrm{L}$ was found to be the anti rotamer based on the large coupling constant, ${ }^{3} J_{\mathrm{H}-55, \mathrm{H}-56}=10 \mathrm{~Hz}$, and supported by the fact that no NOE was observed for H-55/H-56 (Figure S9).

Carbohydrate Identification by NMR, LC-MS/HRMS, and GC-MS Analysis. The LC-MS/HRMS analysis showed a neutral loss matching the presence of a hexose in prymnesin-B1 (Figure 1B). The nature of the hexose was further investigated using both NMR data and GC-MS analysis of the acidhydrolyzed sample. The hydrolysis of the ${ }^{13} \mathrm{C}$-enriched sample and subsequent GC-MS detection as an oxime-TMS derivative $^{21}$ established that the hexose was a galactose, based on comparison with sugar standards (see Figure S10). Next the sugar was derivatized with $\mathrm{N}$-methyl-bis-trifluoroacetamide (MBTFA) to the corresponding trifluoroacetyl ester and analyzed by chiral-phase GC-MS, ${ }^{22}$ altogether establishing that prymnesin-B1 contained a D-galactose (see Figure S10). The precise attachment of the galactose in prymnesin-B1 was established by a long-range HSQC experiment (optimized for ${ }^{n} J_{\mathrm{CH}}=12 \mathrm{~Hz}$ ) to C-71. This attachment was further supported by the deshielded ${ }^{13} \mathrm{C}$ chemical shift $\left(\delta_{13 \mathrm{C}}=90.3 \mathrm{ppm}\right)$ of this carbon as well as a NOE correlation between $\mathrm{H}-1^{\prime}$ and $\mathrm{H}-71$. The galactosyl unit was identified as an $\alpha$-D-galactopyranosyl form evident from a ${ }^{3} J_{\mathrm{H}-1^{\prime}, \mathrm{H}-2^{\prime}}=4 \mathrm{~Hz}$ and ${ }^{13} \mathrm{C}$ chemical shift values. $^{23}$
The LC-MS/HRMS and GC-MS analyses also revealed the presence of a minor component (prymnesin-B2), not observed in the ${ }^{1} \mathrm{H}$ NMR spectrum. The LC-MS/HRMS spectrum clearly indicated the impurity to have the same backbone aglycone ion as seen for prymnesin-B1 and to have a neutral loss $(m / z 66.021$, doubly charged) matching that of a pentose unit (Figure 1B), which could be further established to be Dribose by chiral-phase GC-MS (see Figure S10). The NMR assignment of the ribose moiety of the minor prymnesin-B2 was unsuccessful due to its presence in trace amounts, which is why the exact connectivity of the sugar moiety in prymnesin-B2 could not be resolved. However, we speculate it to be attached to the same oxygen atom as in prymnesin-B1.

Mass Spectrometric Analysis Indicated Numerous Prymnesin-like Compounds in $10 \mathrm{P}$. parvum Strains. Having defined a novel B-type prymnesin, we were encouraged to explore the distribution and chemical nature of prymnesins across several strains. Hence, a total of 10 P. parvum strains, sampled from Europe, Scandinavia, USA, Japan, Australia, and Madagascar, were purified by normal-phase SPE columns $\left(\mathrm{NH}_{2}\right.$ functionalized silica) and screened by means of LC-DAD-MS/ HRMS. Interestingly, the original prymnesins ${ }^{11}$ were detected in only one strain (UTEX-2797), whereas four strains produced up to five B-type prymnesins all having the same elemental 
Table 2. Masses of Detected Ions and Predicted Elemental Compositions of the 16 Prymnesins Reported in This Study, Including Prymnesin-1 and -2 Originally Described by Igarashi et al. ${ }^{16}$

\begin{tabular}{|c|c|c|c|c|c|}
\hline & name & elemental composition & {$[\mathrm{M}+2 \mathrm{H}]^{2+}$} & elemental composistion of aglycone & {$[\mathrm{M} \text {-glycone }+2 \mathrm{H}]^{2-}$} \\
\hline \multirow[t]{3}{*}{ A-type } & Prymnesin-1 & $\begin{array}{c}\mathrm{C}_{107} \mathrm{H}_{154} \mathrm{Cl}_{3} \mathrm{NO}_{44} \\
(\Delta-1.3 \mathrm{ppm})\end{array}$ & 1131.9542 & $\begin{array}{c}\mathrm{C}_{91} \mathrm{H}_{128} \mathrm{Cl}_{3} \mathrm{NO}_{31} \\
(\Delta-1.3 \mathrm{ppm})\end{array}$ & 918.8853 \\
\hline & Prymnesin-2 & $\begin{array}{c}\mathrm{C}_{96} \mathrm{H}_{136} \mathrm{Cl}_{3} \mathrm{NO}_{35} \\
(\Delta 0.0 \mathrm{ppm})\end{array}$ & 984.9052 & $\begin{array}{c}\mathrm{C}_{91} \mathrm{H}_{128} \mathrm{Cl}_{3} \mathrm{NO}_{31} \\
(\Delta-0.4 \mathrm{ppm})\end{array}$ & 918.8837 \\
\hline & & $\begin{array}{l}\mathrm{C}_{96} \mathrm{H}_{137} \mathrm{Cl}_{2} \mathrm{NO}_{35} \\
(\Delta-0.01 \mathrm{ppm})\end{array}$ & 967.9247 & $\begin{array}{c}\mathrm{C}_{91} \mathrm{H}_{129} \mathrm{Cl}_{2} \mathrm{NO}_{31} \\
(\Delta-0.2 \mathrm{ppm})\end{array}$ & 901.9037 \\
\hline \multirow[t]{5}{*}{ B-type } & Prymnesin-B1 & $\begin{array}{c}\mathrm{C}_{91} \mathrm{H}_{132} \mathrm{ClNO}_{34} \\
(\Delta 0.04 \mathrm{ppm})\end{array}$ & 909.9232 & $\begin{array}{c}\mathrm{C}_{85} \mathrm{H}_{122} \mathrm{ClNO}_{29} \\
(\Delta 0.4 \mathrm{ppm})\end{array}$ & 828.8965 \\
\hline & Prymnesin-B $2^{a}$ & $\begin{array}{l}\mathrm{C}_{90} \mathrm{H}_{130} \mathrm{ClNO}_{33} \\
(\Delta-0.05 \mathrm{ppm})\end{array}$ & 894.9180 & $\begin{array}{c}\mathrm{C}_{85} \mathrm{H}_{122} \mathrm{ClNO}_{29} \\
(\Delta 1.0 \mathrm{ppm})\end{array}$ & 828.8960 \\
\hline & & $\begin{array}{c}\mathrm{C}_{96} \mathrm{H}_{140} \mathrm{ClNO}_{38} \\
(\Delta 0.07 \mathrm{ppm})\end{array}$ & 975.9443 & $\begin{array}{c}\mathrm{C}_{85} \mathrm{H}_{122} \mathrm{ClNO}_{29} \\
(\Delta-0.7 \mathrm{ppm})\end{array}$ & 828.8974 \\
\hline & & $\begin{array}{c}\mathrm{C}_{97} \mathrm{H}_{142} \mathrm{ClNO}_{39} \\
(\Delta 1.7 \mathrm{ppm})\end{array}$ & 990.9480 & $\begin{array}{c}\mathrm{C}_{85} \mathrm{H}_{122} \mathrm{ClNO}_{29} \\
(\Delta 0.8 \mathrm{ppm})\end{array}$ & 828.8962 \\
\hline & & $\begin{array}{c}\mathrm{C}_{85} \mathrm{H}_{122} \mathrm{ClNO}_{29} \\
(\Delta 0.03 \mathrm{ppm})\end{array}$ & 828.8968 & $\begin{array}{c}\mathrm{C}_{85} \mathrm{H}_{122} \mathrm{ClNO}_{29} \\
(\Delta 0.03 \mathrm{ppm})\end{array}$ & 828.8968 \\
\hline \multirow[t]{8}{*}{ C-type } & & $\begin{array}{c}\mathrm{C}_{88} \mathrm{H}_{125} \mathrm{Cl}_{2} \mathrm{NO}_{35} \\
(\Delta 0.04 \mathrm{ppm})\end{array}$ & 913.8777 & $\begin{array}{c}\mathrm{C}_{83} \mathrm{H}_{117} \mathrm{Cl}_{2} \mathrm{NO}_{31} \\
(\Delta 2.0 \mathrm{ppm})\end{array}$ & 847.8549 \\
\hline & & $\begin{array}{l}\mathrm{C}_{88} \mathrm{H}_{127} \mathrm{Cl}_{2} \mathrm{NO}_{35} \\
(\Delta-0.04 \mathrm{ppm})\end{array}$ & 914.8856 & $\begin{array}{c}\mathrm{C}_{83} \mathrm{H}_{119} \mathrm{Cl}_{2} \mathrm{NO}_{31} \\
(\Delta 1.7 \mathrm{ppm})\end{array}$ & 848.8630 \\
\hline & & $\begin{array}{c}\mathrm{C}_{93} \mathrm{H}_{135} \mathrm{Cl}_{2} \mathrm{NO}_{39} \\
(\Delta 3.0 \mathrm{ppm})\end{array}$ & 980.9037 & $\begin{array}{c}\mathrm{C}_{83} \mathrm{H}_{119} \mathrm{Cl}_{2} \mathrm{NO}_{31} \\
(\Delta 0.3 \mathrm{ppm})\end{array}$ & 848.8642 \\
\hline & & $\begin{array}{l}\mathrm{C}_{88} \mathrm{H}_{126} \mathrm{Cl}_{3} \mathrm{NO}_{35} \\
(\Delta-0.02 \mathrm{ppm})\end{array}$ & 931.8661 & $\begin{array}{c}\mathrm{C}_{83} \mathrm{H}_{118} \mathrm{Cl}_{3} \mathrm{NO}_{31} \\
(\Delta 2.1 \mathrm{ppm})\end{array}$ & 865.8431 \\
\hline & & $\begin{array}{c}\mathrm{C}_{88} \mathrm{H}_{124} \mathrm{Cl}_{3} \mathrm{NO}_{35} \\
(\Delta 2.7 \mathrm{ppm})\end{array}$ & 930.8557 & $\begin{array}{c}\mathrm{C}_{83} \mathrm{H}_{116} \mathrm{Cl}_{3} \mathrm{NO}_{31} \\
(\Delta 1.6 \mathrm{ppm})\end{array}$ & 864.8357 \\
\hline & & $\begin{array}{c}\mathrm{C}_{99} \mathrm{H}_{144} \mathrm{Cl}_{3} \mathrm{NO}_{44} \\
(\Delta 1.2 \mathrm{ppm})\end{array}$ & 1078.9123 & $\begin{array}{c}\mathrm{C}_{83} \mathrm{H}_{118} \mathrm{Cl}_{3} \mathrm{NO}_{31} \\
(\Delta-1.3 \mathrm{ppm})\end{array}$ & 865.8461 \\
\hline & & $\begin{array}{c}\mathrm{C}_{93} \mathrm{H}_{134} \mathrm{Cl}_{3} \mathrm{NO}_{39} \\
(\Delta 2.1 \mathrm{ppm})\end{array}$ & 997.8851 & $\begin{array}{c}\mathrm{C}_{83} \mathrm{H}_{118} \mathrm{Cl}_{3} \mathrm{NO}_{31} \\
(\Delta 1.4 \mathrm{ppm})\end{array}$ & 865.8437 \\
\hline & & $\begin{array}{c}\mathrm{C}_{88} \mathrm{H}_{125} \mathrm{Cl}_{4} \mathrm{NO}_{35} \\
(\Delta 0.5 \mathrm{ppm})\end{array}$ & 948.8461 & $\begin{array}{c}\mathrm{C}_{83} \mathrm{H}_{117} \mathrm{Cl}_{4} \mathrm{NO}_{31} \\
(\Delta 0.1 \mathrm{ppm})\end{array}$ & 882.8254 \\
\hline
\end{tabular}

composistion of their aglycone part $\left(\mathrm{C}_{85} \mathrm{H}_{122} \mathrm{ClNO}_{29}\right)$, as described above for prymnesin-B1 (Figure 1, Table 2).

The last five strains produced neither the original prymnesins nor the novel B-type prymnesins (Table 2 and Table S1). Excitingly, they instead contained peaks detected as doubly charged adducts with complex isotopic patterns (Figure 1B), clearly indicating them to be an even third type of chlorinated prymnesins. The interpretation of the MS/HRMS data for this tentative C-type of prymnesins was more challenging, as we also observed variation in their degree of chlorination. However, in all cases we found these tentative C-type prymnesins to contain a $\mathrm{C}_{83}$ backbone (Table 2 and Table $\mathrm{S} 1)$. All three prymnesin types showed similar chromatographic behavior on an $\mathrm{NH}_{2}$ SPE column and similar UV spectra and fragmentation patterns. Altogether, these MS-DAD-based investigations indicate the production of at least 16 different prymnesins that can be further subdivided into three types (original, B-type, and C-type).

The current study includes Scandinavian $P$. parvum strains, strains from the English Channel, and strains isolated from various parts of the world distant from Europe, near Madagascar, Japan, and Australia, and from Texas (Figure 1). Our screen currently points to some degree of regional preference of prymnesin chemotypes (e.g., mostly B-type in northern European strains), but to an overall diverse worldwide distribution of the different types of prymnesins.

Biosynthesis of Prymnesins. Our findings of three types of prymnesins suggest that evolution of the polyketide biosynthetic machinery in $P$. parvum has led to the variety of prymnesin backbone structures observed here. Previous investigations on the biosynthesis of algal polyketides in dinoflagellates $^{24}$ have shown that formation of the backbone polyketide chains often is not as simple as in, for example, filamentous fungi, where the growing chain usually is extended with two carbons each time. Algal polyethers on the contrary, such as the six-membered fused ring system of yessotoxin, have been shown to be formed by repeated condensation of a unit consisting of a methyl group (derived from an acetate unit) and an intact acetate unit. ${ }^{25}$ Future biosynthetic studies, such as $\left[2-{ }^{13} \mathrm{C}\right]$-acetate incorporation studies, ${ }^{26}$ will have to reveal how the assembly of different backbones takes place in prymnesins and especially why the backbone of the novel B-type prymnesins is six carbons shorter than that of the original prymnesins, leading to the lack of a complete 1,6-dioxadecalin core unit.

Bioactivity of Prymnesin-B1. A comparison of the bioactivity of prymnesin-2 and prymnesin-B1 was complicated due to the fact that the solubility of the compounds was extremely low after purification. In order to quantify the 
amount of prymnesins in solution, the amino groups of the compounds were covalently tagged with 6-aminoquinolyl- $\mathrm{N}$ hydroxysuccinimidyl carbamate (AccQ tag), yielding a fluorescent product, whose concentration could be externally calibrated using the amino group containing mycotoxin fumonisin $B_{1}$ (certified reference solution) by UHPLC-FLD (Figure S11). This approach allowed us to establish accurate concentrations, showing that the prymnesin-B1 lysed the RTgill-W1 cells with an $\mathrm{EC}_{50}$ value in the nanomolar range $(5.98 \pm 0.65 \mathrm{nM})$, similar to the more homogeneous and slightly more toxic prymnesin-2 $\left(\mathrm{EC}_{50}=0.92 \pm 0.05 \mathrm{nM}\right.$, mean values $\pm \mathrm{SE}$ ) (Figure 2). Consequently, we speculate that all

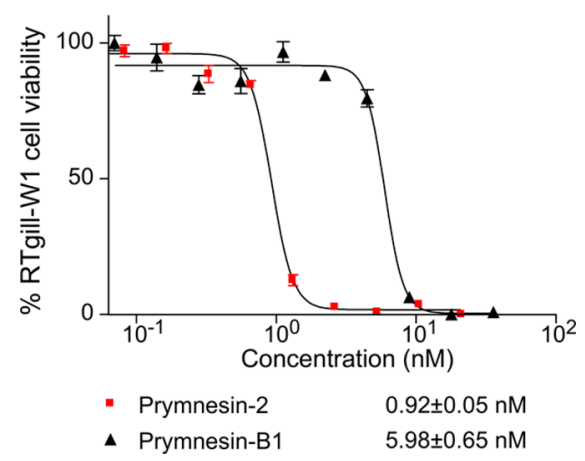

Figure 2. Dose-response curves for prymnesin-2 and prymnesin-B1 using an RTgill-W1 cell assay on the externally calibrated prymnesin standards. The reported $\mathrm{EC}_{50}$ values $(n=9$ replicates per concentration, symbols represent mean values \pm SE) are after $3 \mathrm{~h}$ of exposure.

prymnesins are ichthyotoxic and that mixtures of several prymnesins in combination are responsible for the massive recent fish kills observed worldwide.

In conclusion, our work is the first in 20 years to address the chemistry and structural diversity of prymnesins produced by the ichthyotoxic alga $P$. parvum. The chemodiversity of these toxins is proven to be much higher than previously realized, explaining why it has been so challenging to detect previously described prymnesins in various recent instances of algal blooms. At the same time, our studies call for targeted multiprymnesin analytical methods for the analysis of these very toxic compounds in future, fish-killing algal blooms.

\section{EXPERIMENTAL SECTION}

General Experimental Procedures. The optical rotation was measured in $\mathrm{MeOH}$ using a PerkinElmer model 241 polarimeter. The IR spectrum was measured on a Bruker ALPHA Platinum ATR FT-IR spectrometer. NMR spectra were recorded in $\mathrm{CD}_{3} \mathrm{OD}$ (99.96 atom \%, Sigma-Aldrich). All data were acquired on a Bruker Avance II 800 $\mathrm{MHz}$ spectrometer equipped with a TCI Z-gradient CryoProbe and an 18.7 T magnet (Oxford Magnet Technology). Standard 1D, 2D NOESY, 2D COSY, and 2D TOCSY spectra were recorded on the nonenriched sample, whereas heteronuclear $2 \mathrm{D}$ and $3 \mathrm{D}$ experiments were recorded on the ${ }^{13} \mathrm{C}$-enriched version at $313 \mathrm{~K}$. These experiments encompass ${ }^{1} \mathrm{H}-{ }^{13} \mathrm{C}$ CT-HSQC, ${ }^{1} \mathrm{H}-{ }^{13} \mathrm{C}$ HMBC, LR- ${ }^{1} \mathrm{H}-{ }^{13} \mathrm{C}-\mathrm{CT}-\mathrm{HSQC}$, and HCCH-TOCSY. Deuterium exchange was carried out in $\mathrm{CD}_{3} \mathrm{OH}$ (99.8 atom \%, Sigma-Aldrich) at $293 \mathrm{~K}$ as compared to a sample in $\mathrm{CD}_{3} \mathrm{OD}$ (99.96 atom \%, Sigma-Aldrich) at 293 K. Further details on NMR experiments are provided in the Supporting Information. High-resolution mass spectra were obtained on a MaXis HD QTOF-MS (Bruker Daltronics). The mass spectrometer was optimized to accommodate the larger ions by setting the collision cell parameters: transfer time to $100 \mu$ s together with collision RF to $1500 \mathrm{Vpp}$ and a prepulse storage of $10 \mu \mathrm{s}$. MS/
MS was carried out by operating the qTOFMS in targeted MS/MS mode (using 10 and $20 \mathrm{eV}$ ); the $[\mathrm{M}+2 \mathrm{H}]^{2+}$ ions were selected for fragmentation, as the single charged ions of prymnesin did not generate any fragments. Analytical UHPLC was performed on an Ultima 3000 UHPLC (Dionex) using a $100 \times 2 \mathrm{~mm}, 2.6 \mu$ m Kinetex $\mathrm{C}_{18}$ column (Phenomenex). The column was eluted by a linear $\mathrm{MeCN}-\mathrm{H}_{2} \mathrm{O}$ gradient, containing $20 \mathrm{mM}$ formic acid, from $10 \%$ to $100 \% \mathrm{MeCN}$ in $10 \mathrm{~min}$, held at this composition for $2 \mathrm{~min}$ before returning to starting conditions at a flow rate of $0.4 \mathrm{~mL} / \mathrm{min}$. All solvents were purchased from Sigma-Aldrich and were HPLC grade for extraction and isolation work. For LC-HRMS, all solvents and additives were LC-MS grade.

Algal Cultivation and Harvesting. Nonaxenic algal cultures were obtained from the Scandinavian Culture Collection for Algae and Protozoa, the Marine Biological Section of the University of Copenhagen, the University of Texas Culture Collection of Algae, and Kalmar Algae Collection. Cultures were maintained in autoclaved seawater with $\mathrm{f} / 2$ nutrition kept at $15{ }^{\circ} \mathrm{C}$ and an irradiance of 250 $\mu \mathrm{mol}$ photons $\mathrm{m}^{-2} \mathrm{~s}^{-1}$. All cultures were harvested in late exponential phase, $20 \mathrm{~L}$ at a time. Artificial seawater was prepared as described by Kester et al. ${ }^{27}$ All cultures were assessed by cell numbers, and the $\mathrm{pH}$ was measured. Large volumes for the isolation of toxins were centrifuged by means of continuous centrifugation using an Avanti Series equipped with a JCF-Z rotor $(3500 \mathrm{G}, 40 \mathrm{~mL} / \mathrm{min}$, Beckman Coulter). The P. parvum strain K-0081 was used for cultivation of the novel B-type prymnesin-B1.

Isolation of Prymnesin-B1. The cell pellet $\left(3.0 \times 10^{10}\right.$ cells $)$ was extracted with cold acetone followed by $\mathrm{MeOH}$. The methanolic extract was then separated on amino-propyl-derivatized silica (10 g, Biotage) using a stepwise elution with $\mathrm{CH}_{2} \mathrm{Cl}_{2}$ and EtOAc followed by $\mathrm{MeOH}$. Final isolation of prymnesin-B1 was achieved on a $250 \times 10$ $\mathrm{mm}, 5 \mu \mathrm{m}$ Gemini Phenyl column (Phenomenex) using a gradient of (A) $\mathrm{H}_{2} \mathrm{O}$ and (B) $\mathrm{MeCN}-i \operatorname{PrOH}(1: 1)$ both containing $10 \mathrm{mM}$ formic acid at a flow rate of $4 \mathrm{~mL} / \mathrm{min}$ from $37 \% \mathrm{~B}$ in $30 \mathrm{~min}$.

Prymnesin-B1: pale yellow powder; $[\alpha]_{\mathrm{D}}^{25}+7.5(\mathrm{c} 0.08, \mathrm{MeOH})$; UV $\lambda_{\max } 280,268 ; \mathrm{IR} \nu_{\max } 3400,1680,1440,1200,1136 \mathrm{~cm}^{-1} ;{ }^{1} \mathrm{H}$ and ${ }^{13} \mathrm{C}$ NMR data Table 1; HREIMS $\mathrm{m} / z 1818.8390$ (calcd for $\left.\mathrm{C}_{91} \mathrm{H}_{132} \mathrm{ClNO}_{34}, 1818.8392\right)$.

Isolation of Prymnesin-2. Prymnesin-2 was isolated from the biomass $\left(1.0 \times 10^{10}\right.$ cells $)$ of a $100 \mathrm{~L}$ culture of $P$. parvum UTEX-2797 similar to that of prymnesin-B1, but the final isolation was achieved on the Gemini Phenyl column using a gradient of (B) $\mathrm{MeCN}-i \mathrm{PrOH}$ (1:1) and (A) $\mathrm{H}_{2} \mathrm{O}(45-55 \% \mathrm{~B}$ in $30 \mathrm{~min})$ both containing $5 \mathrm{ppm}$ TFA at a flow rate of $4 \mathrm{~mL} / \mathrm{min}$.

Sugar Analysis. Saturated prymnesins in $\mathrm{MeOH}(10 \mu \mathrm{L})$ were hydrolyzed by $6 \mathrm{M}$ TFA in LC-MS-grade DI $\mathrm{H}_{2} \mathrm{O}$ (Sigma-Aldrich) at $70{ }^{\circ} \mathrm{C}$ for $1 \mathrm{~h}$ and then evaporated to dryness under a stream of $\mathrm{N}_{2}$. The hydrolyzed sample was reacted with $10 \mu \mathrm{L}$ of $O$-methylhydroxylamine hydrochloride in pyridine $(40 \mathrm{mg} / \mathrm{mL})$ for $90 \mathrm{~min}$ at $40{ }^{\circ} \mathrm{C}$, followed by $90 \mu \mathrm{L}$ of $N$-methyl- $N$-trimethylsilyltrifluoroacetamide (MSTFA) with $1 \%$ trimethylchlorosilane (TMCS) (1 mL ampules, Thermo-Scientific, Waltham MA) and heated to $40{ }^{\circ} \mathrm{C}$ for $30 \mathrm{~min}$ for trimethylsilylation. The product was then analyzed on a $30 \mathrm{~m} \times 0.25$ $\mathrm{mm} \times 0.25 \mu \mathrm{m}$ DB5 capillary column (Agilent Technologies, Santa Clara, CA, USA) programmed to $60-325^{\circ} \mathrm{C}$ at $10^{\circ} \mathrm{C} / \mathrm{min}$. For chiralphase analysis, the sample was reacted with $10 \mu \mathrm{L}$ of $N$-methyl-bistrifluoroacetamide (MBTFA) (GC-grade, 99\%, Sigma-Aldrich) and 40 $\mu \mathrm{L}$ of dry pyridine and then heated to $65^{\circ} \mathrm{C}$ for $40 \mathrm{~min}$. The sample was cooled to room temperature and subsequently analyzed on a CPChiraSil-L-Val GC column $(25 \mathrm{~m} \times 0.25 \mathrm{~mm} \times 0.12 \mu \mathrm{m}$, Agilent Technologies) programmed to $70-150{ }^{\circ} \mathrm{C}$ at $4 \%$ min using an HP 6890 series GC system and Agilent 5973 mass selective detector. The sample was compared to the standards, D-arabinose, D-xylose, Lgalactose, (>99\%, Sigma-Aldrich), D-ribose (>99\%, Merck), Larabinose, D-galactose (>97\%, Sigma-Aldrich), L-lyxose, L-ribose, and L-xylose (>99\%, CarboSynth Ltd.).

Prymnesin Calibration. Prymnesin was dissolved in $\mathrm{MeOH}$. A 10 $\mu \mathrm{L}$ amount was added to $60 \mu \mathrm{L}$ of pyridine, the mixture was vortexed, and $20 \mu \mathrm{L}$ of AccQ tag reagent (Waters) was added. This reaction mixture was immediately vortexed and left for $1 \mathrm{~min}$ at room 
temperature followed by $10 \mathrm{~min}$ at $55{ }^{\circ} \mathrm{C}$. Excess reagent was quenched by addition of $10 \mu \mathrm{L}$ of Milli-Q $\mathrm{H}_{2} \mathrm{O}$ (resulting in a final dilution factor of 1/10). A fumonisin-B1 (Romer Labs) calibration curve was prepared by serial dilution, each dilution, $10 \mu \mathrm{L}$, by its individual reaction with $20 \mu \mathrm{L}$ of AccQ tag and $70 \mu \mathrm{L}$ of borate buffer. Analysis was performed on an Ultima 3000 UHPLC (Dionex) equipped with a 1200 series fluorescence detector (Agilent), with $\lambda_{\mathrm{ex}}=$ 250 and $\lambda_{\text {em }}=395 \mathrm{~nm}$. Separation was achieved on a $100 \times 2 \mathrm{~mm}, 1.7$ $\mu \mathrm{m}$ Kinetex $\mathrm{C}_{18}$ column (Phenomenex) using a $\mathrm{MeCN}-\mathrm{H}_{2} \mathrm{O}$ gradient containing $50 \mathrm{ppm}$ TFA at a flow rate of $0.4 \mathrm{~mL} / \mathrm{min}$.

RTgill-W1 Cell Assay. Purified and calibrated toxins in $\mathrm{MeOH}$ (highest $\mathrm{MeOH}$ concentration in assay was $1 \%$ ) were added in 10 concentrations in a serial dilution manner ( 7 replicates) to a 96-well plate (TPP) containing 20000 RTgill-W1 cells per well. The cells had been plated $48 \mathrm{~h}$ prior to the experiment in $200 \mu \mathrm{L}$ well ${ }^{-1}$ BioWhittaker Leibovitz's L-15 media (Lonza). The gill cells were incubated in the dark at $19{ }^{\circ} \mathrm{C}$ for $3 \mathrm{~h}$, and subsequently $100 \mu \mathrm{L}$ of L15 media with 5\% Presto Blue cell viability reagent (Invitrogen) was added to each well and left for incubation for $30 \mathrm{~min}$ under identical conditions. $^{28}$ The plates were read on a FLUOstar OPTIMA plate reader (BMG LABTECH) with $\lambda_{\mathrm{ex}}=540 \mathrm{~nm}$ and $\lambda_{\mathrm{em}}=590 \mathrm{~nm}$. The viability of the gill cells was calculated as percentage of an L-15 media control. A control plate with $\mathrm{MeOH}$ starting at $5 \%$ in $\mathrm{L}-15$ media did not show any cell viability at the highest tested $\mathrm{MeOH}$ concentration.

\section{ASSOCIATED CONTENT}

\section{S Supporting Information}

The Supporting Information is available free of charge on the ACS Publications website at DOI: 10.1021/acs.jnatprod.6b00345.

NMR spectroscopic data, GC-MS, UHPLC-FLD; detailed relative configuration analysis (PDF)

\section{AUTHOR INFORMATION}

\section{Corresponding Authors}

*Tel (P. J. Hansen): (+45) 35321985. E-mail: pjhansen@bio. ku.dk.

*Tel (T. O. Larsen): (+45) 45252632. E-mail: tol@bio.dtu.dk.

Notes

The authors declare no competing financial interest.

\section{ACKNOWLEDGMENTS}

NMR spectra were recorded on the $800 \mathrm{MHz}$ spectrometer of the Danish National Instrument Center for NMR Spectroscopy of Biological Macromolecules at the Carlsberg Laboratory and the Technical University of Denmark. We gratefully acknowledge B. O. Petersen for initial NMR measurements and L. S. de Medeiros for help with the AccQ tag method. In addition, we are grateful to the late $\mathrm{C}$. Christophersen for many valuable discussions on marine natural product chemistry during the past 20 years. This study was supported by the Danish Council for Strategic Research through the project "HABFISH", Project No. 0603-00449B, and through the Carlsberg Foundation Grants 2013_01_0709 and CF14-0422.

\section{REFERENCES}

(1) Barkoh, A.; Fries, L. T. J. Am. Water Resour. Assoc. 2010, 46, 1-5.

(2) Roelke, D. L.; Barkoh, A.; Brooks, B. W.; Grover, J. P.; Hambright, K. D.; Laclaire, J. W.; Peter, I. I. Hydrobiologia 2016, 764, $29-50$.

(3) Southard, G. M.; Fries, L. T.; Barkoh, A. J. Am. Water Resour. Assoc. 2010, 46, 14-23.

(4) Johnsen, T. M.; Eikrem, W.; Olseng, C. D.; Tollefsen, K. E.; Bjerknes, V. J. Am. Water Resour. Assoc. 2010, 46, 6-13.

(5) Ulitzur, S.; Shilo, M. J. Gen. Microbiol. 1964, 36, 161-169.
(6) Igarashi, T.; Satake, M.; Yasumoto, T. J. Am. Chem. Soc. 1996, $118,479-480$.

(7) Sasaki, M.; Takeda, N.; Fuwa, H.; Watanabe, R.; Satake, M.; Oshima, Y. Tetrahedron Lett. 2006, 47, 5687-5691.

(8) Sasaki, M.; Ebine, M.; Takagi, H.; Takakura, H.; Shida, T.; Satake, M.; Oshima, Y.; Igarashi, T.; Yasumoto, T. Org. Lett. 2004, 6, 15011504.

(9) Sasaki, M.; Shida, T.; Tachibana, K. Tetrahedron Lett. 2001, 42, 5725-5728.

(10) Morohashi, A.; Satake, M.; Oshima, Y.; Igamshi, T.; Yasumoto, T. Chirality 2001, 13, 601-605.

(11) Manning, S. R.; La Claire, J. W. Anal. Biochem. 2013, 442, 189195.

(12) Bertin, M. J.; Zimba, P. V.; Beauchesne, K. R.; Huncik, K. M.; Moeller, P. D. R. Harmful Algae 2012, 20, 111-116.

(13) Bertin, M. J.; Zimba, P. V.; Beauchesne, K. R.; Huncik, K. M.; Moeller, P. D. R. Harmful Algae 2012, 20, 117-125.

(14) Henrikson, J. C.; Gharfeh, M. S.; Easton, A. C.; Easton, J. D.; Glenn, K. L.; Shadfan, M.; Mooberry, S. L.; Hambright, K. D.; Cichewicz, R. H. Toxicon 2010, 55, 1396-1404.

(15) Blossom, H. E.; Rasmussen, S. A.; Andersen, N. G.; Larsen, T. O.; Nielsen, K. F.; Hansen, P. J. Aquat. Toxicol. 2014, 157, 159-166.

(16) Igarashi, T.; Satake, M.; Yasumoto, T. J. Am. Chem. Soc. 1999, $121,8499-8511$.

(17) Murata, M.; Yasumoto, T. Nat. Prod. Rep. 2000, 17, 293-314.

(18) Pfeffer, P. E.; Valentine, K. M.; Parrish, F. W. J. Am. Chem. Soc. 1979, 101, 1265-1274.

(19) Hamamoto, Y.; Tachibana, K.; Holland, P. T.; Shi, F.; Beuzenberg, V.; Itoh, Y.; Satake, M. J. Am. Chem. Soc. 2012, 134, 4963-4968.

(20) Rasmussen, S. A.; Andersen, A. J. C.; Andersen, N. G.; Nielsen, K. F.; Hansen, P. J.; Larsen, T. O. J. Nat. Prod. 2016, 79, 662-673.

(21) Kind, T.; Wohlgemuth, G.; Lee, D. Y.; Lu, Y.; Palazoglu, M.; Shahbaz, S.; Fiehn, O. Anal. Chem. 2009, 81, 10038-10048.

(22) König, W. A.; Benecke, I.; Bretting, H. Angew. Chem., Int. Ed. Engl. 1981, 20, 693-694.

(23) Bock, K.; Pedersen, C. Adv. Carbohydr. Chem. Biochem. 1983, 41, 27-66.

(24) Van Wagoner, R. M.; Satake, M.; Wright, J. L. C. Nat. Prod. Rep. 2014, 31, 1101.

(25) Yamazaki, M.; Tachibana, K.; Satake, M. Tetrahedron 2011, 67, 877-880.

(26) Meng, Y.; Van Wagoner, R. M.; Misner, I.; Tomas, C.; Wright, J. L. C. J. Nat. Prod. 2010, 73, 409-415.

(27) Kester, D. R.; Duedall, I. W.; Connors, D. N.; Pytkowicz, R. M. Limnol. Oceanogr. 1967, 12, 176-179.

(28) Dayeh, V. R.; Bols, N. C.; Tanneberger, K.; Schirmer, K.; Lee, L. E. J. Curr. Protoc. Toxicol. 2013, 56, 1-20. 